\title{
Obituaries
}

\section{Paul Francis Wehrle}

Paediatrician and researcher who gained an international reputation for diagnosing and developing
treatments for polio and smallpox

Before Paul Francis Wehrle joined the University of Southern California (USC) department of paediatrics as its chairman in 1961 , academic research was a relatively low priority for a staff focused on delivering an average of 40-50 babies per day. Operating on a longstanding apprentice system of doctors, fitting volunteer teaching rounds in between attending to their patients, the department of paediatrics boasted a strong team of clinicians but little impetus for research.

But during his tenure as chairman of USC's department of paediatrics from 1961 to 1988 , Wehrle, a paediatrician and expert on infectious and communicable diseases, not only oversaw the running of the busy county hospital, but transformed it into a well respected centre for medical research.

"When Professor Wehrle first arrived, USC didn't have much of an academic reputation," said Professor Joan Hodgman, who has been on the faculty of USC's paediatrics department since 1948 and was a close colleague of Wehrle's. "He would travel all over the world waving the flag for USC." It was not for nothing that the USC medical school staff dubbed their chairman "our visiting professor."

Wehrle's research interests sent him all over the globe. In 1969, on a sabbatical from USC, he spent a year working as a medical officer for the Geneva-based World Health Organization (WHO) on a campaign to eradicate smallpox. He travelled to Africa, South America, Nepal, India, and Afghanistan, lecturing and immunising people against the disease. The WHO mandate also involved training local people in these areas to give vaccinations to members of their communities and providing better vaccines than were available at that time.

In the same year, Wehrle also conducted a study of an outbreak of smallpox in a German hospital, contributing to the understanding that virus particles of the disease could be carried some distance through the air to infect other people. "To this day, Wehrle's study remains one of the best demonstrations of the airborne transmission of smallpox," Dr John Leedom, emeritus professor of medicine at USC, told the New

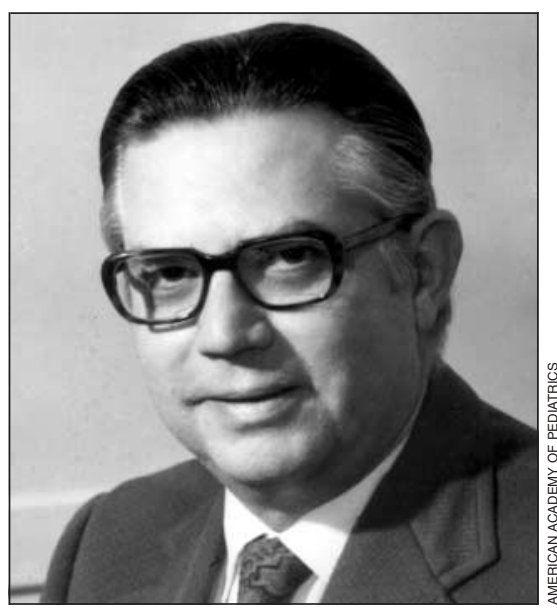

being recruited to head the paediatrics unit at USC. In the early 1950s, Wehrle worked on the clinical trials of the Salk polio vaccine, which was first administered in 1954.

Wehrle held key positions within many professional societies, including serving as president and vice president of the American Academy of Pediatrics and president of the International Congress of Paediatrics. He also served on the Air Pollution Training Committee of the US Public Health Service.

But even with his strong reputation, turning USC Medical School into a research powerhouse was an uphill struggle for Wehrle. Raising money was one of the biggest obstacles. Beyond the fact that USC was not highly regarded as a centre for academic research, the county hospital did not allocate funds for "ancillary reasons." However, according to Hodgman, the greatest challenge facing Wehrle stood beyond the powers of hospital administrators. "County bureaucracy made life hard," said Hodgman. "There was always less money and more regulations."

Having served his term as chairman, Wehrle moved to a more administrative role in the Medical School director's office. But because, according to Hodgman, he was a "hands on" doctor, Wehrle only lasted two years in this job before moving to a new position as interim chairman of paediatrics at the University of California at Irvine.

Wehrle continued to write and consult for as long as his health would allow. He died of natural causes on 11 May 2004 at the age of 82 in San Clemente, California. Described by his sister-in-law Marcia Sanford in an article for the Arizona Daily Star as a "downto-earth person" who enjoyed repairing classic cars, Wehrle also played saxophone in a local swing band as a young man growing up in Tucson, before joining the Navy in 1942.

Wehrle leaves his wife of 59 years, Beth; and four children. [Chloe Veltman]

Paul Francis Wehrle, chairman Department of Pediatrics, USC Medical School, 1961-1988 and interim chairman of paediatrics, The University of California at Irvine (b 1921; $q$ Tulane University 1947) died on 11 May 2004 


\section{Richard Gore Benians}

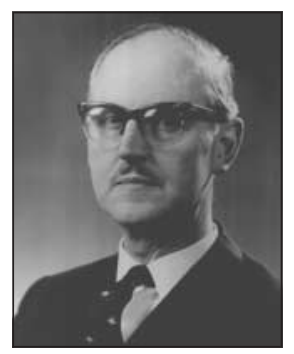

Former geriatrician Southend (b 1916; $q$ Cambridge 1940; FRCP,MD), died on 27 December 2003

Richard considered a career in paediatrics, but his revulsion at the death of some of the premature babies dissuaded him. Ever practical, Richard turned his hand to constructing home made incubators from scrap materials. He served in the Royal Army Medical Corps in Syria, Egypt, and Palestine, and he took part in the Sicily landings. In 1959 he was appointed consultant geriatrician and physician in Southend, where he worked until retirement in 1986. Richard was a dinghy sailor and a keen experimental horticulturalist, and made wine out of everything. He leaves a wife, Edith Florence; three children; and eight grandchildren. [RoBIN BENIANS]

\section{Harbaksh Singh Capoore}

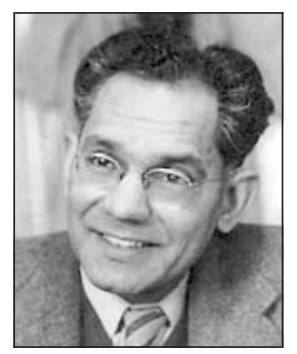

Former consultant psychiatrist Bexley Hospital and honorary consultant Kent and Canterbury Hospital (b Lucknow, India, 191 7; q Leeds 1943; DPM, MD, FRCPsych), died from carcinomatosis on 23 August 2003

Buns, as he was known, came to England in 1934, studying dentistry in Leeds before qualifying in medicine. In 1949 he was appointed consultant to Bexley Hospital and later to St Vincent's Approved School. He participated in the great changes in psychiatry, including the coming of antipsychotics and antidepressants, the opening of locked wards, and the closure of the large mental hospitals. After retirement he continued to attend paediatric ward rounds until a few months before his death. He had an interest in fast cars and continued to drive his Porsche until a few weeks before his death. Predeceased by his wife, he leaves a daughter. [P CApoore, M Hirons, J Hood]

\section{Malcolm "Callum” Walker Clark}

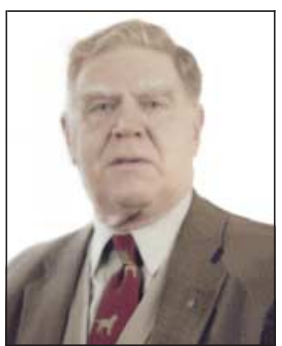

Former general medical practitioner Durham City (b 1923; q Glasgow 1947), died from pneumonia on 9 March 2004

Callum, after graduating, spent two years in the Royal Army Medical Corps in Egypt, before returning for a short stint in general practice in Birmingham. In 1951 he moved to Durham City, where he remained for nearly 40 years. He took an active part in the education of St John Ambulance and worked for the health board after his retirement. He took every opportunity to maintain his links with Scotland through the Durham \& District Caledonian Society, holidays, and sporting occasions. Predeceased by his wife, Nan, he leaves four children and nine grandchildren. [Drew Clark, Stuart Clark]

\section{Philip Haigh}

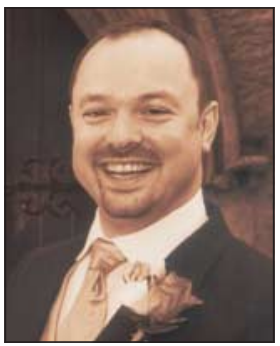

Specialist registrar in gastroenterology London (b 1970; q Southampton 1993),

died in a motorcycle crash on 15 February 2004 Phil never lost his Welsh heritage despite schooling and training in England. He had wanted to be a doctor from an early age. An interest in liver disease resulted in research for an MD, several publications, and recently rotation to the Royal Free Hospital Liver Unit. His dry sense of humour, cheeky grin, and infectious laugh are precious memories for all who knew him. Phil leaves a wife, Sarah. [ANDrew Burroughs, Rodney BURNHAM]

\section{Gillian Anne Hartley}

Former staff grade physician in elderly care medicine Telford (b 1968; q London 1991), died in a road traffic incident on 15 May 2004

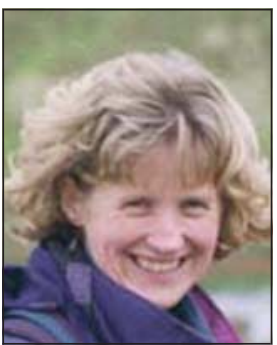

After house jobs, Gillian worked in elderly care at Frenchay Hospital, Bristol, and then moved to Shropshire, working in ENT and ophthalmology, and gaining her diploma in ENT. She then moved into general practice, completing her training at a rural practice on the Welsh border. Later, Gillian returned to elderly care medicine, which she loved. After starting her family she was hoping to return to general practice. Gillian had a passion for hill walking, and climbing, and she was a member of Wrekin Mountaineering Club. She leaves a partner, Eric, and a daughter. [SANDRA CHARLES]

\section{Thomas Loftus Townshend Lewis}

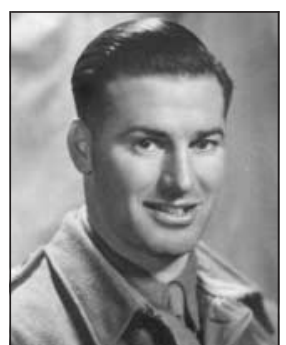

Former consultant obstetrician and gynaecologist London (b 1918; q Cambridge 1942; FRCS, MRCOG), died on 9 April 2004 Thomas was appointed consultant at Guy's Hospital just before the formation of the National Health Service in 1948, and two years later at Queen Charlotte's Maternity Hospital for Women. He wrote three text books, and Progress in Clinical Obstetrics $\mathcal{E}$ Gynaecology became a world classic. $\mathrm{He}$ served three times on the Council of the Royal College of Obstetricians and Gynaecologists; he was its honorary secretary between 1961 and 1968, and senior vice president from 1975 to 1978 . He was president of the obstetric section of the Royal Society of Medicine. He served in the Royal Army Medical Corps, and he was consultant gynaecologist to the army and examiner to several universities. He was awarded a CBE for his contributions to his specialty. He captained and was the president of the Guy's rugby team, and he was selected for England. He leaves a wife, and five children. [Tim Coltart, John Lewis, Anthony KENNY]

Longer versions of these obituaries are available on bmj.com 